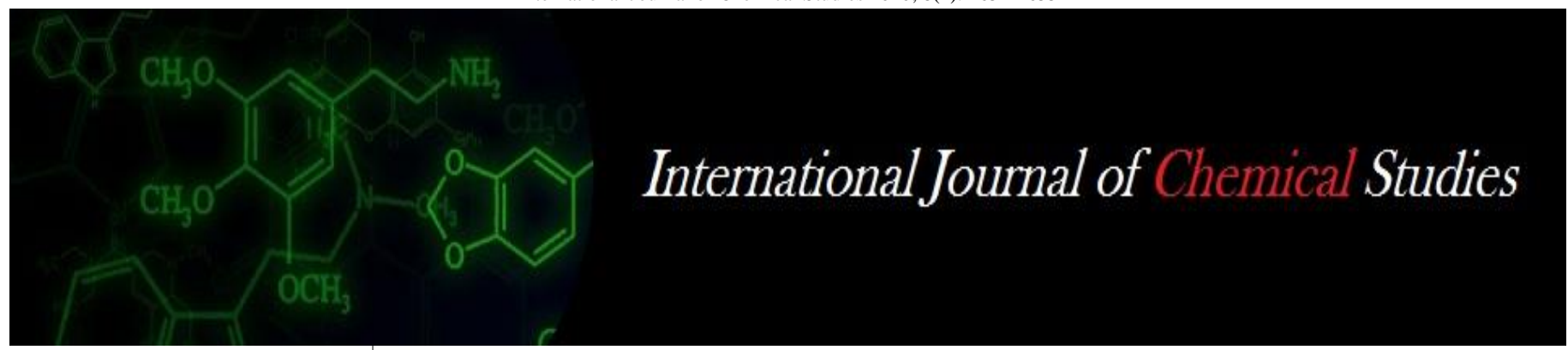

P-ISSN: 2349-8528

E-ISSN: 2321-4902

IJCS 2020; 8(1): 1651-1655

(C) 2020 IJCS

Received: 13-11-2019

Accepted: 15-12-2019

\section{B Panigrahi}

Professor, Department of Soil

and Water Conservation

Engineering, CAET, OUAT,

Bhubaneswar, Odisha, India

\section{Paramjita}

Scientist (Agril. Engg.), K, V.K.,

Puri, OUAT, Bhubaneswar,

Odisha, India

AP Sahu

Professor, Department of Soil and Water Conservation

Engineering, CAET, OUAT, Bhubaneswar, Odisha, India
Corresponding Author: B Panigrahi

Professor, Department of Soil and Water Conservation

Engineering, CAET, OUAT,

Bhubaneswar, Odisha, India

\section{Enhancing water productivity in rainfed areas}

\author{
B Panigrahi, D Paramjita and AP Sahu
}

DOI: https://doi.org/10.22271/chemi.2020.v8.i1x.8500

\begin{abstract}
Odisha is an agrarian state. About $66 \%$ people depend on agriculture. Agriculture in the state is primarily rainfed dependent. Only about $35 \%$ of the cultivated areas in the state is irrigated. Rainfed agriculture in the region is mostly dependent on south-west monsoon. But the rainfall distribution is very uneven and erratic. Onset of monsoon and withdrawal of monsoon are very erratic. In addition, there is frequent occurrence of in-season critical dry spells which hampers the yield of rice seriously. Almost every alternate year or so, there is either flood or drought that affects the yield seriously. The average y2ield of rice in rainfed condition is around $1.5 \mathrm{t} / \mathrm{ha}$ whereas the average rice yield under irrigated condition is about $4 \mathrm{t} / \mathrm{ha}$. In rabi season, there is hardly any rainfall. So farmers generally grow only one crop in kharif season and that is mostly rice. In rabi season, hardly any crop is grown in rainfed areas since there is no facility of irrigation and there is scanty rainfall. It is very crucial to enhance the water productivity of crops in this rainfed dependent agriculture. In this paper various opportunities to enhance water productivity of rainfed agriculture are discussed. Scientific water management, farm pond based irrigation management system and irrigation methods including high tech irrigation are discussed in this paper for enhancing water productivity of various crops under rainfed scenario.
\end{abstract}

Keywords: Enhancing water productivity, rainfed areas

\section{Introduction}

The state of Odisha is rich with rainfall resources. On an average there is $1450 \mathrm{~mm}$ annual rainfall out of which $76 \%$ occurs in kharif season (June to September). Most of the rainfall flows past over the soil causing a lot of soil, water and nutrient erosion and subsequently the eroded soils get deposited in the reservoir causing reduced capacity of the reservoir. This water is a valuable resource and needs to be stored for further use as supplemental irrigation.

\section{Farm pond technology for enhancing water productivity}

Conservation of rainwater in small farm pond and its subsequent utilisation in the crops can enhance the water productivity and thereby increasing production and productivity of different crops including rice. Small farm ponds are gaining popularity amongst the rice farmers since the technology of water harvesting and supplemental irrigation through farm pond is not very high and cost involved in its construction is also not high. The farmers themselves can dug a small pond in their own fields and maintain it. The Govt. and various funding agencies including NABARD sometimes gives loan for construction of ponds. One big advantage of water harvesting in farm pond is that farmers can manage it at his own wills. He can use the stored water of the pond at his own wills and at his convenience. He can choose what crops he likes to grow depending on the availability of stored water. In other words, it is a handy source for the farmers. They can also grow a second crop in their fields using life saving irrigation of water stored in the pond.

Studies reveal that a polythene lined farm pond with $10 \%$ farm area of depth 2 to $3 \mathrm{~m}$ can supply 2 to 3 supplemental irrigation of $5 \mathrm{~cm}$ each to rice during critical growth stages (critical growth stages of rice are: tillering, panicle initiation, milking and doughing) and can enhance yield up to $50 \%$. The yield of rice with provision of such supplemental irrigation can go up to 3 t/ha. For double cropping system i.e. rice in kharif season followed by a low water requiring crop like mustard in rabi season, the pond size required is about $12 \%$ under polythene lined system ((Panigrahi, 2001; Panigrahi and Panda, 2003) ${ }^{[7,5]}$. Instead of polythene, farmers can also go for other low budget lining materials like bentonite or soil cement lining. 
But considering the durability and reduction of seepage volume, polythene lined ponds are preferred. The payback period of this polythene lined ponds can be obtained as 5 to 6 years. The life span of the pond being about 20-25 years, the farm pond irrigation system is proved to be economically viable for the farmers. If the pond is used for integrated farming system with pisciculture, than pay back period will be less (4 -5 years) and the system will be more remunerative.

Some farmers, those who cannot afford lining of the system, may go for unlined pond. But if the soil is porous and course textured like sandy loam soil, lining is highly required to check high seepage losses of the water. For unlined farm pond, the pond size requirement is more than lined case. It is reported by researchers that the unlined farm pond with $12 \%$ farm area of depth 2 to $3 \mathrm{~m}$ can supply 2 to 3 supplemental irrigation of $5 \mathrm{~cm}$ each to rice during critical growth stages and can enhance yield by about 30 - 50\%. For double cropping system i.e. rice in kharif season followed by a low water requiring crop like mustard in rabi season, the pond size required is about $15 \%$ under unlined system.

\section{Irrigation scheduling for enhancing water productivity}

Irrigation scheduling plays critical role in enhancing water use efficiency. Farmers must provide the precise amount of water to the crops at right time. Though there are many scientific methods to know when to irrigate the crops, farmers can simply see the crop and soil condition and decide when to irrigate. When there are hair cracks in the soil, or leaves of plants fade or become slightly yellow, they decide it is the time for irrigation. An experienced farmer is the best judge to approximately decide when to irrigate his own crop Water being a precious resource in rainfed farming system, its judicious use by right method of irrigation at the most responsive stage (critical growth stage) is very important. It is preferable to use the harvested water of the pond as lifesaving irrigation which will increase the water use efficiency of crop. Farmers should know the different critical growth stage of crops which will help them to provide life-saving irrigation. They are as follows (Table 1) (Panigrahi, 2011) ${ }^{[8]}$.

Table 1: Critical growth stages of crops

\begin{tabular}{|c|c|c|}
\hline Sl. No. & Crops & Critical stages \\
\hline 1. & Wheat & CRI, flowering \\
\hline 2. & Barley & 30 days after sowing, pre-flowering \\
\hline 3. & Potato & Sprouting, early tuberisation \\
\hline 4. & Gram & Pre-flowering \\
\hline 5. & Soybean & Pre-flowering, pod development \\
\hline 6. & Rice & Early tillering, flowering \\
\hline 7. & Sorghum & Flowering \\
\hline 8. & Maize & Tasseling and silking \\
\hline 9. & Cotton & Pre-flowering, boll formation \\
\hline 10. & Sugarcane & Sprouting \\
\hline 11. & Groundnut & Flowering, pod formation \\
\hline 12. & Mustard & Flowering \\
\hline
\end{tabular}

Different crops need different amount of water to grow. There are some crops like rice which needs high amount of water whereas crops like pulses need low amount. Farmers must know which crop needs how much water to grow. Accordingly, they can decide the crops basing on the availability of water. Water requirement of crops are shown below in a Table 2 (Panigrahi et al., 1992) ${ }^{[6]}$.
Table 2: Water requirement of crops

\begin{tabular}{|c|c|c|}
\hline Crop & Duration & Water requirement, cm \\
\hline Rice (transplanted) & $90-150$ & $70-120$ \\
\hline Rice (direct sown) & $92-110$ & $37-46$ \\
\hline Wheat & $95-115$ & $35-40$ \\
\hline Maize & $95-120$ & $50-60$ \\
\hline Ragi & $85-130$ & $40-65$ \\
\hline Jowar & $110-125$ & $55-65$ \\
\hline Bajra & $115-120$ & $45-50$ \\
\hline Greengram (Winter) & 75 & 15 \\
\hline Greengram (Summer) & 70 & 25 \\
\hline Blackgram & 90 & 20 \\
\hline Horsegram & 90 & 15 \\
\hline Peas & 138 & 15 \\
\hline Groundnut (kharif) & 110 & 48 \\
\hline Groundnut (summer) & 120 & 55 \\
\hline Sesamum & 90 & 25 \\
\hline Mustard & 100 & 30 \\
\hline Castor & 130 & 50 \\
\hline Linseed & 85 & 35 \\
\hline Jute & $120-130$ & 48 \\
\hline Sugarcane & 300 & 170 \\
\hline Cotton & 120 & 62 \\
\hline Potato & $75-110$ & $47-65$ \\
\hline Tomato & 100 & 50 \\
\hline Lady's finger & 90 & 45 \\
\hline Chillies & 120 & 52 \\
\hline Tobacco & 110 & 36 \\
\hline Onion & 115 & 70 \\
\hline Cabbage & 70 & 60 \\
\hline
\end{tabular}

\section{Scientific water management to enhance water proidcutivity}

Most of the farmers over use the amount of water for irrigation. It is observed that most of the farmers maintain medium to deep submergence in rice field and thereby they over use the water. This practice of submergence not only decreases the productivity of crop but also increases the water use and consequently the water productivity decreases. Some of the water saving irrigation techniques used for enhancing water productivity is as follows:

- Water saving irrigation (WSI) should be practiced in rice and rice based cropping systems instead of continuous wet environment

- Intermittent irrigation schedule instead of shallow/medium submergence can save about 20\% irrigation water and increase rice yield and water-useefficiency by $30 \%$

- Crops should be irrigated at critical growth stages with life-saving irrigation.

- Irrigate kharif paddy at 3 days after disappearance of ponded water (ADP) and rabi paddy at 1 ADP.

- Researches by the water management scientists have proved that WSI techniques can save $15-20 \%$ irrigation water which enables short duration low water requiring crop like mustard, green gram, black gram etc. to be grown.

\section{Water use efficiency of different crops}

It is imperative to know the water use efficiency (WUE) of different crops so that the framers can opt what crops he would grow in his fields depending on the input like water ha has. Table 3 below summarises the water use efficiency of different crop. 
Table 3: Water use efficiency of different crops

\begin{tabular}{|c|c|c|c|}
\hline Crop & WR $(\mathbf{m m})$ & Yield (kg/ha) & WUE, (kg/ha-mm) \\
\hline Sugarcane & 1700 & 100000 & 58.8 \\
\hline Potato & 500 & 20000 & 40.0 \\
\hline Maize & 500 & 4000 & 8.0 \\
\hline Groundnut & 480 & 2500 & 5.2 \\
\hline Sunflower & 400 & 2000 & 5.0 \\
\hline Mustard & 300 & 1400 & 4.7 \\
\hline Sesame & 250 & 1000 & 4.0 \\
\hline Greengram & 250 & 1000 & 4.0 \\
\hline Jute & 480 & 2800 & 5.8 \\
\hline Rice & 1200 & 4000 & 3.3 \\
\hline
\end{tabular}

\section{Methods of irrigation}

Methods of irrigation are another important technique to enhance water use efficiency of crops in rainfed farming situation. Irrigation through drip and sprinkler systems saves a lot of costly irrigation water and thereby augments water use efficiency.

\section{High tech irrigation (drip and sprinkler)}

High tech irrigation like drip and sprinkler has many advantages. They are:

- High application efficiency

- Low runoff and percolation loss

- Low weed growth

- High productivity of crops

- High water saving

- Suitable for all crops and land topography

- Ideal for all vegetables, orchard crops and plantation crops

- High water productivity

\section{Advantages of drip irrigation over surface irrigation}

Generally the farmers in Odisha are irrigating their crop field by surface method of irrigation. But this method uses more amount of water since there is no control over it. There is more losses in the crop filed $\mathrm{s}$ as seepage and percolation. Consequently, the water sue efficiency of the crops are less. On the other hand drip irrigation uses low but frequent amount of water and has high application efficiency. The following table (Table 4) summarises the saving of water by drip over the surface irrigation and also summarises the yield enhancement.

Table 4: Comparison of water savings and yield advantages of drip over surface method of irrigation

\begin{tabular}{|c|c|c|}
\hline Crop & Water saving (\%) & Yield advantage (\%) \\
\hline Sugarcane & 30 & 20 \\
\hline Cotton & 60 & 25 \\
\hline Groundnut & 40 & 66 \\
\hline Potato & 54 & 69 \\
\hline Onion & 50 & 20 \\
\hline Tomato & 78 & 44 \\
\hline Brinjal & 62 & 63 \\
\hline Chilli & 62 & 44 \\
\hline Okra & 84 & 13 \\
\hline Banana & 45 & 52 \\
\hline Coconut & 65 & 12 \\
\hline Papaya & 68 & 77 \\
\hline
\end{tabular}

Increasing water productivity - some field investigations

Numerous experimental data are available on application of supplemental irrigation to different crops at different critical growth stages and their consequential affect on increase in yield, water-use efficiency and economic returns. In this section, the results of a few research works are reported. The result of an experiment at ICRISAT, Hyderabad show that 5 $\mathrm{cm}$ supplemental irrigation in alfisol applied to sorghum (at grain-filling stage) and maize (at pre-tasseling stage) increased yields of both the crops by more than 100 percent. However, pear millet showed an increase of 17-59 percent and sunflower 27-32 percent (Anonymous, 1976) ${ }^{[1]}$.

The results of multi-location trials carried out at different locations of India on one supplemental irrigation to rainfed crops are presented in Table 5 (Singh, 1983) ${ }^{[9]}$. It is seen from the table that in the northen part of India, wheat has maximum response to supplemental irrigation which varies from place to place. A $5 \mathrm{~cm}$ irrigation given at critical stages of wheat, barley, sorghum and rice at 10 different stations of the country increased yield from 15.3 to $23.8 \mathrm{q} /$ ha with efficiency of water use $20.9 \mathrm{~kg} / \mathrm{ha} / \mathrm{mm}$ (Venkateswaralu and Singh, 1982) ${ }^{[10]}$.

Table 5: Effect of one supplemental irrigation $(5 \mathrm{~cm})$ on yield of rainfed cops

\begin{tabular}{|c|c|c|c|c|c|}
\hline \multirow[t]{2}{*}{ Crop } & \multirow[t]{2}{*}{ Station } & \multirow[t]{2}{*}{ No of trials } & \multicolumn{2}{|c|}{ Yield, q/ha } & \multirow[t]{2}{*}{ WUE kg/ha/cm } \\
\hline & & & Without irrigation & With irrigation & \\
\hline Wheat & Dehradun & 4 & 21.4 & 35.5 & 282 \\
\hline Wheat & Jodhpur & 4 & 19. & 36.0 & 324 \\
\hline Wheat & Ludhina & 4 & 19.2 & 41.1 & 431 \\
\hline Wheat & Agra & 2 & 21.9 & 27.4 & 110 \\
\hline Wheat & Rawa & 4 & 5.7 & 18.8 & 262 \\
\hline Barley & Varanasi & 2 & 26.0 & 33.6 & 148 \\
\hline Barley & Ranchi & - & 5.5 & 11.7 & 124 \\
\hline Sorghum & Bijapur & 5 & 16.5 & 23.6 & 148 \\
\hline Sorghum & Bellary & 4 & 4.3 & 13.7 & 182 \\
\hline Sorghum & Solapur & 5 & 9.8 & 18.2 & 168 \\
\hline Sorghum & Hyderabad & 2 & 13.9 & 19.2 & 106 \\
\hline Sorghum & Kovilpatti & 3 & 27.8 & 28.9 & 22 \\
\hline Upland rice & Rawa & 4 & 16.2 & 27.8 & 232 \\
\hline Bidi tobacco & Anand & 4 & 12.1 & 18.1 & 120 \\
\hline Finger millet & Bangalore & - & 16.2 & 23.2 & 140 \\
\hline Pearlmillet & Jodhpur & 4 & 16.6 & 19.0 & 48 \\
\hline Pigeon pes & Jhansi & - & 0.5 & 3.3 & 56 \\
\hline Sunflower & Bellary & - & 1.3 & 2.9 & 32 \\
\hline Rapseed & Randhi & - & 2.5 & 5.4 & 58 \\
\hline Chilles & Bangalore & - & 2.1 & 4.5 & 48 \\
\hline
\end{tabular}




\begin{tabular}{|c|c|c|c|c|c|}
\hline Bidi tobacco & Vasad & 2 & 14.6 & 17.5 & 58 \\
\hline Safflower & Vasad & 1 & 15.6 & 20.2 & 92 \\
\hline Mstard & Vasad & 1 & 16.5 & 20.4 & 74 \\
\hline Gram & Vasad & 1 & 10. & 16.3 & 110 \\
\hline Cowpea & Vasad & 1 & 20.4 & 20.8 & 7.6 \\
\hline
\end{tabular}

Verma et al. (1984) ${ }^{[12]}$ have reviewed the available literatures on supplemental irrigation to wheat and maize. Majority of research workers has suggested 5 to $6 \mathrm{~cm}$ supplemental irrigation to wheat at early stress especially at pre sowing stage (in case of deficient seeding zone moisture) or at CSRI stage of wheat. In case of maize, tesseling - silking stage has been found most critical for a supplemental irrigation. In northern India an irrigation of $5 \mathrm{~cm}$ at pre-sowing or at CRI stage increased rainfed wheat grain yield by $7.7 \mathrm{~g} / \mathrm{ha}$ (Verma, 1981) ${ }^{[11]}$. According to Gajri et al. (1983) ${ }^{[4]}$ a supplemental irrigation to rainfed wheat increased grain yield by 30 to 81 percent. Time of application, quantity of water for irrigation, and selection of crop types are extensively important factors which need to be considered to derive the maximum benefits. Life-saving irrigation at the most crop responsive stage i.e. critical growth stage shall not only protect the crops but help to stabilize the production. The results of supplemental irrigation in medium deep black soils at Bijapur over a period of 5 years indicates that crop yields with one life saving irrigation of $5 \mathrm{~cm}$ can enhance the yield by 40-90 percent (Table 6, Belgaumi, et al., 1997) ${ }^{[3]}$.

Table 6: Response of crops to life saving irrigation in medium deep black soil at Bijapur

\begin{tabular}{|c|c|c|c|}
\hline Crop & \multicolumn{2}{|c|}{$\begin{array}{c}\text { Yield, kg/ha Control } \\
\text { Irrigated }\end{array}$} & $\begin{array}{c}\text { Yield increase (\%) } \\
\text { over control) }\end{array}$ \\
\hline Sorghum (Rabi) & 1845 & 2574 & 39.5 \\
\hline Safflower & 1196 & 1702 & 42.4 \\
\hline Bengalgram & 669 & 887 & 32.5 \\
\hline Sunflower & 873 & 1429 & 63.7 \\
\hline Redgram & 198 & 381 & 92.4 \\
\hline Hybrid cotton & 1094 & 1524 & 39.3 \\
\hline
\end{tabular}

Pond irrigation system also plays crucial role in increasing the productivity and income generation capacity of farmers in farming system approach. This system gave higher returns as compared to sole crop of paddy served by pond irrigation. The data obtained at Bijapur on different farming systems revealed that horticultural crops with ber plantations (cv. Umran and Kadaka) recorded gross income ranging between Rs. 27,962 to Rs. 37,260 per hectare with two to three supplemental irrigations as against Rs. 23,657 to Rs. 29,505 per hectare in control from the ber plantation. The next highest income was obtained from the cultivation of curry leaf (Rs. 26, 664 per hectare) with two supplemental irrigations followed by hybrid cotton (Rs. 18,840 per hectare). Intercropping of bengalgram + safflower in row proportion of 4:2 provided only Rs. 4937 per hectare with two supplemental irrigations where as the income from the arable cropping system was Rs. 3488 under control. Cultivation of mulberry, pastures (grass + legumes) under protective irrigations accounted Rs. 16,870 and Rs. 5107 per hectare, respectively against corresponding income of Rs. 14,385 and Rs. 4121 per hectare under control (Table 7, Anonymous, 1991) ${ }^{[2]}$.

Table 7: Yield and gross income of different farming systems as influenced by pond irrigation

\begin{tabular}{|c|c|c|c|}
\hline \multicolumn{2}{|c|}{ Farming system } & $\begin{array}{c}\text { Average } \\
\text { yield (kg/ha) }\end{array}$ & $\begin{array}{c}\text { Gross income } \\
\text { (Rs./ha) }\end{array}$ \\
\hline Ber (Umran) & Irrigated & 7452 & 37260 \\
\hline & Control & 5901 & 29505 \\
\hline Ber (Kadaka) & Irrigated & 5592 & 27962 \\
\hline Curry leaf & Control & 4731 & 23657 \\
\hline Mulberry & Irrigated & 8888 & 26664 \\
\hline & Irrigated & 7216 & 16870 \\
\hline Pastures & Control & 6245 & 14385 \\
\hline Hybrid cotton & Irrigated & 29915 & 5107 \\
\hline & Irrigated & 1884 & 18840 \\
\hline $\begin{array}{c}\text { Bengalgram+Safflowe } \\
\text { r intercropping (4:2) }\end{array}$ & Irrigated & 17260 & 4937 \\
\hline
\end{tabular}

From the foregoing presentations, it is evident that the response for extensive irrigation with limited supply is more compared to the intensive irrigation. Besides the extensive irrigation, another important consideration to maximize the economic returns from the harvested water of the pond is the method of irrigation. It is advisable to use micro-irrigation techniques for irrigating the crops from the pond stored water. The micro-irrigation like drip and sprinkler has very high application efficiency to the tune of $85-90 \%$. At Bijapur, it has been observed that drip irrigation could save $50 \%$ of pond water compared to the surface method of irrigation (Belgaumi et al., 1997) ${ }^{[3]}$. The following table (Table 8) gives the response of a given amount of supplemental irrigation in different fruit crops by different methods of irrigation (Belgaumi et al., 1997) ${ }^{[3]}$. From this table it is evident that the drip method of irrigation gives highest fruit yield than other methods.

Table 8: Response of methods of irrigation on fruit yield of different plants for a irrigation supply of 200 lit/plant

\begin{tabular}{|c|c|c|c|c|c|c|}
\hline Methods of irrigation & \multicolumn{3}{|c|}{ Fruit yield, kg/plant Ber Fig Pomegranate } & \multicolumn{3}{|c|}{ Percent increase over control Ber Fig Pomegranate } \\
\hline Drip & 6.17 & 2.73 & 3.36 & 252 & 228 & 133 \\
\hline Jet & 5.07 & 1.90 & 2.20 & 189 & 128 & 52 \\
\hline Surface & 4.37 & 1.51 & 2.31 & 149 & 82 & 60 \\
\hline Control & 1.75 & 0.83 & 1.44 & -- & -- & --- \\
\hline
\end{tabular}

To maximize the economic returns from the harvested water of the pond, integrated farm system is advisable. The integrated farming system will help to the increase the incomes from different sources like increased yield of crops from the farms, additional income in rearing fish in the pond, returns from yield of banana, coconut, papaya, arhar etc. grown in the embankment of the ponds. A photo of a pond with cultivation of banana and arhar in the embankment of a newly constructed pond is presented in Fig. 1. Fig. 2 shows the photo of another farm pond constructed in chronically waterlogged ecosystem in the farm of regional research and technology transfer station of Chiplima, Odisha where fish are 
reared in the pond and banana and guava crops are grown in the embankment of the pond. In addition, the stored water of the pond is used to irrigate the rice crops. Thus, the pond acts as a viable source for integrated farming system and helps the farmers to raise their income from multi-source.

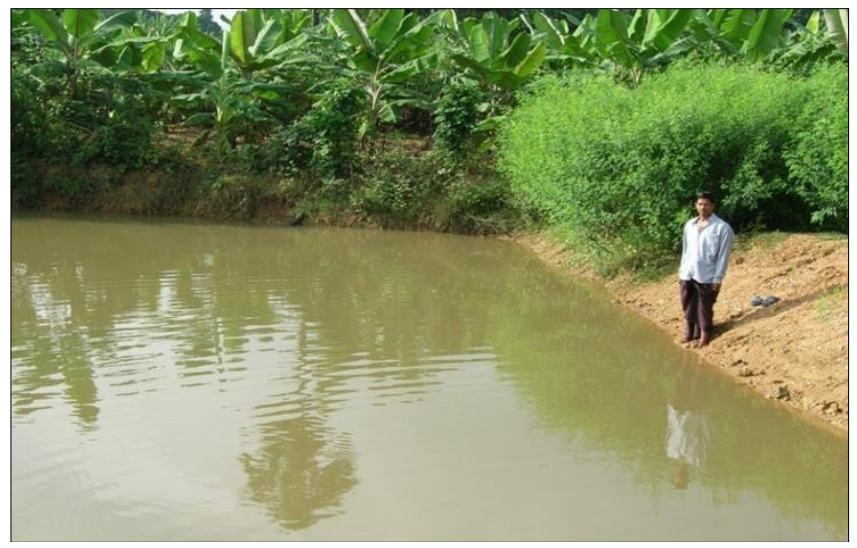

Fig 1: Banana and arhar grown in embankment of a farm pond

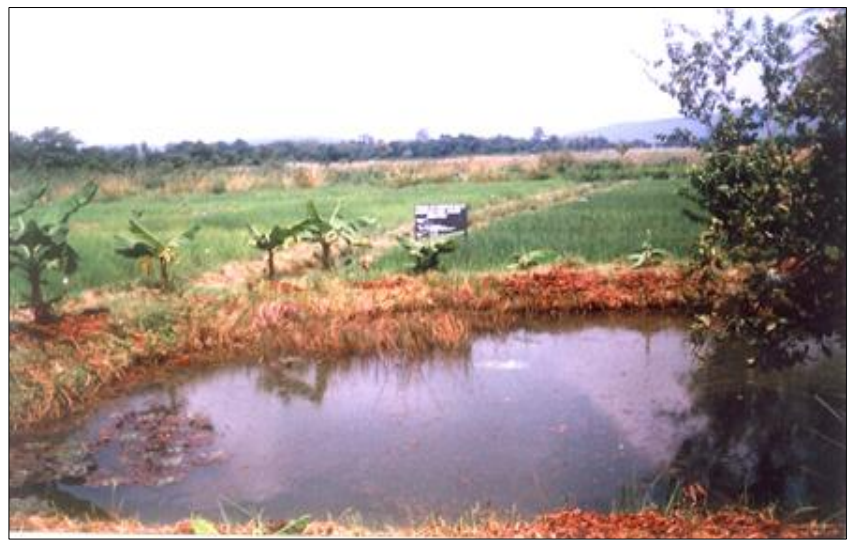

Fig 2: Farm pond for multiuse at Chiplima, Odisha

\section{Conclusions}

Water saving irrigation technique is an innovation for increasing water productivity in rainfed areas. Various water saving irrigation techniques including scientific water management in rice and non-rice crops, irrigation methods including drip and sprinklers, irrigation scheduling and farm pond technologies for integrated farming systems have been discussed in this paper. Several field experimental data done by different researchers at different regions on various crops with water saving irrigation technologies are also discussed in this paper. In is reported from various field experiments that about 30 to $70 \%$ irrigation water can be saved by advanced method of irrigation and water productivity to the tune of 20 to $60 \%$ can be enhanced by adopting various water saving irrigation technologies.

\section{References}

1. Anonymous. Annual Report of International Crop Research Institute for the Semi-Arid Tropics, Hyderabad, 1976, 80.

2. Anonymous. Annual Progress Report of All India CoOrdinated Research Project on Dryland Agriculture, Bijapur, 1991.

3. Belgaumi MI, Itnal CJ, Radder CD. Farm Ponds. Technical series 4, Publication Centrte, University of Agricultural Sciences, Dharwad, 1997, 47.
4. Gajri PR, Verma HN, Parihar SS. Rain water harvesting and its recycling for maximization of crop production. Indian J Soil Conserv. 1983; 9(2\&3):116-123.

5. Panigrahi B, Panda SN. Optimal Sizing of On-Farm Reservoir for Supplemental Irrigation. Journal of Irrigation and Drainage Engineering, ASCE. 2003; 129(2):117-128.

6. Panigrahi B, Sharma SD, Behera BP. Irrigation Water Requirement Models of Some Major Crops, Water Resources Management. 1992; 6(1):69-77.

7. Panigrahi B. Water Balance Simulation for Optimum Design of On-Farm Reservoir in Rainfed Farming System. Unpublished Ph. D thesis submitted to IIT, Kharagpur, 2001.

8. Panigrahi B. Irrigation Systems Engineering, New India Publishing Agency, New Delhi, 2011, 325.

9. Singh RP. Farm Pond. Project Bulletin No. 6, All India Co-ordinated Research Project on Dryland Agriculture, Hyderabad, 1983.

10. Venkateswaralu J, ANS Singh SN. Crop management to mitigate moisture stress. In a decade of dry land agriculture research in India (1971-80). All India CoOrdinated Research Project on Dryland Agriculture, Hyderabad, 1982, 48-50.

11. Verma HN. Water harvesting for life saving irrigation of rainfed crops in the sub-mountain region of Punjab. $\mathrm{J}$ of Agric. Engrg. (Indian Soc. of Agril. Engineers). 1981; 18(3\&4):64-72.

12. Verma HN, Prihar SS, Singh R. Feasibility of storage of runoff in dugout ponds and its use for supplemental irrigation in submontane Punjab. Indian J Soil Conserv. $1984 ; 12(1): 31-36$ 